\title{
DESINFESTAÇÃO DE REBENTOS DE SISAL PARA UTILIZAÇÃO IN VITRO
}

\section{DISINFESTATION OF SISAL SHOOTS FOR USE IN VITRO}

\author{
Flavia Monique Sales Nobrega ${ }^{1}$ \\ Taíza da Cunha Soares ${ }^{1}$ \\ Alberto Soares de Melo² \\ Julita Maria Frota Chagas Carvalho ${ }^{3}$
}

Resumo: Em todo o mundo, o sisal (Agave sisalana) é conhecido pelo alto teor de suas fibras, amplamente utilizadas na fabricação de utensílios, na indústria automotiva, na indústria química e na construção cívil. No entanto, alguns fatores podem inviabilizar o desenvolvimento da cultura, a exemplo de doenças, como a podridão do colo, causada por fungos do gênero Pythium sp. Visando à obtenção de mudas sadias e livres de patógenos buscou-se, com este trabalho, definir um protocolo eficiente para a desinfestação de rebentos de sisal, utilizandose diferentes concentrações e diversas combinações do antibiótico Citrofloxacino e do Fungicida Baytan®. Os explantes foram desinfestados em soluções com detergente neutro, hipoclorito de sódio e formaldeído e, em seguida, submetidos a soluções com diferentes concentrações do antibiótico e do fungicida combinados e só então cultivados em meio MS. Foram realizadas avaliações aos 7, 15 e 21 dias, após o cultivo, para análise da taxa de contaminação bacteriana e fúngica. Observou-se, portanto, que a utilização de $0,5 \%$ do fungicida Baytan $\Theta$, associado a 1\% do antibiótico Citrofloxacino, foi mais eficiente na descontaminação de explantes de sisal.

Palavras-chave: desinfestantes; Agave sisalana; cultivo de tecidos.

Abstract: The sisal (Agave sisalana) is known worldwide for its high fiber content, which is widely used in the manufacture of utensils, as well as in the automotive industry, chemical industry, and construction. However, some factors may prevent the development of this culture, like diseases such as collar rot, caused by fungi of the genus Pythium sp. Trying to obtain healthy seedlings that are free from pathogens, this work set a protocol for efficient disinfection of sisal shoots, using different concentrations and different combinations of the antibiotic Citrofloxacino and the fungicide Baytan $\AA$. The explants were decontaminated with detergent solutions, sodium hypochlorite, and formaldehyde. This was followed by treatment with solutions containing different concentrations of the antibiotic and fungicide combinations. Then, they were cultured on MS medium. Evaluations were made at 7, 15, and 21 days after culture for analysis of the rate of bacterial and fungal contamination. We observed that the use of $0.5 \%$ Baytan ${ }^{3}$ fungicide associated with $1 \%$ of the citrofloxacino antibiotic was the most effective in decontaminating explants sisal.

Keywords: disinfestants; Agave sisalana; tissue culture.

\footnotetext{
${ }^{1}$ Mestra em Ciências Agrárias - Universidade Estadual da Paraíba - UEPB e Estagiária no Laboratório de Cultivo de Tecidos - Embrapa Algodão - Empresa Brasileira de Pesquisa Agropecuária / Ministério da Agricultura, Pecuária e Abastecimento - Mapa. E-mails: flaviasales_bio@hotmail.com; taizacunha@hotmail.com.

${ }^{2}$ Doutor em Recursos Naturais - Universidade Federal de Campina Grande - UFCG, Brasil. Coordenador e docente do Programa de Pós-graduação em Ciências Agrárias - UEPB/Embrapa Algodão. E-mail: alberto@uepb.edu.br.

${ }^{3}$ Doutora em Recursos Fitogenéticos - Universidad Politécnica de Madrid. Docente da Universidade Federal da Paraíba

- UFPB, Brasil e Pesquisador III da Empresa Brasileira de Pesquisa Agropecuária. E-mail: julita@cnpa.embrapa.br.
} 


\section{INTRODUÇÃO}

O Brasil é o principal produtor e exportador de sisal do mundo, produzindo, em 2013, cerca de 243 mil toneladas de fibras (INSTITUTO BRASILEIRO DE GEOGRAFIA E ESTATÍSTICA, 2013), sendo grande parte dessa produção (cerca de $80 \%$ ) exportada para

países como Estados Unidos, China, México e Portugal. A fibra do sisal é largamente utilizada na fabricação de cordas, tapetes e utensílios, além de, também, ser utilizada na indústria química, cívil e automobilística (SILVA; BELTRÃO, 1999).

Alguns fatores, no entanto, interferem no cultivo dessa Agavaceae, a exemplo de doenças, como a podridão do colo, causada por fungos, como Aspergillus níger e Botryodiplodia theobromae Rever, Pat. (LIMA et al., 1998), que vêm afetando cerca de $40 \%$ das lavouras brasileiras de sisal (ALVES; SANTIAGO; LIMA, 2004). Visando à diminuição dos prejuízos causados pela podridão do colo, por intermédio da utilização de mudas sadias pelos produtores de sisal, é necessário o emprego de técnicas modernas de biotecnologia, como a cultura de tecidos que, com base na totipotência celular (CARVALHO; SENA, 2008), produzem mudas sadias e livres de patógenos em curto espaço de tempo, além de conservar as características genéticas do material selecionado (ROSALES et al., 2008). Entretanto, o sucesso da micropropagação depende, em parte, de medidas de controle e prevenção da contaminação por organismos patogênicos, como fungos e bactérias (SILVA, LANK; ÂNGELO, 2003), principalmente quando se utilizam plantas originárias diretamente do campo, as quais estão em contato direto com patógenos presentes no solo (MORAES; ALMEIDA; CAZÉ FILHO, 2007). Esses micro-organismos comprometem o cultivo, uma vez que competem por nutrientes e vitaminas do meio de cultivo, além de produzirem metabólitos fitotóxicos, como ácidos láctico e acético (PEREIRA; FORTES, 2003), inviabilizando, assim, o cultivo in vitro e causando prejuízos econômicos diversos (ODA et al., 2003).

A presença de fungos e bactérias pode ser identificada logo no início do cultivo; entretanto, os maiores problemas dizem respeito aos contaminantes endógenos que permanecem latentes, dificultando a desinfestação e aumentando, portanto, as taxas de contaminação (PEREIRA; MATTOS; FORTES, 2003). Desse modo, a utilização de agentes descontaminantes, como antibióticos e fungicidas, no processo de desinfestação de explantes utilizados in vitro, faz-se necessária (PEREIRA; MATTOS; FORTES, 2003), uma vez que visa ao combate a contaminantes endógenos não destruídos com substâncias usualmente utilizadas no cultivo in vitro, como hipoclorito de sódio, álcool e formol, as quais destroem os contaminantes mais superficiais (exógenos) (PEREIRA et al., 2010).

Normalmente, antibióticos e fungicidas são incorporados ao meio de cultivo, ou utilizados, diretamente, sobre o explante (STANIER; KHOSH-KHUI, 1997); entretanto, a utilização dessas substâncias não elimina totalmente a contaminação. É importante considerar que fatores como a concentração do desinfestante, o tempo de exposição do explante e a cultura trabalhada, são determinantes no índice de desinfestação, o que faz necessária a adequação do protocolo de desinfestação a ser utilizado (MORAES; ALMEIDA; CAZÉ FILHO, 2007). 
Vários estudos avaliando o poder desinfestante de antibióticos e fungicidas têm sido realizados como estratégia ao combate a patógenos em diferentes culturas, no entanto são escassos quando consideradas culturas como o sisal. Desse modo, o presente trabalho teve por objetivo definir um protocolo eficiente de desinfestação de rebentos de sisal para utilização no cultivo in vitro.

\section{METODOLOGIA}

O ensaio foi realizado no Laboratório de Cultivo de Tecidos da Embrapa Algodão. Foram utilizados rebentos de híbridos de sisal, cada um com cerca de $20 \mathrm{~cm}$ de altura, oriundos do banco de germoplasma de sisal da Embrapa Algodão, como fonte de explantes; após a retirada do campo, as plantas doadoras foram levadas para o laboratório, onde foram lavadas, para retirada do excesso de solo, raiz e folhas. Em seguida, as bases foram seccionadas com bisturi estéril, permitindo, dessa forma, a redução do tamanho para o cultivo in vitro. Posteriormente, os explantes foram submersos em solução com detergente neutro a $4 \%(\mathrm{v} / \mathrm{v})$, por 20 minutos, e, então, enxaguados com água esterelizada. Em câmara de fluxo laminar, os explantes foram submersos em solução de formaldeído a $1 \%$ (v/v) e em solução de hipoclorito de sódio a 5\% (v/v), acrescida de 2 gotas de Tween 20, sob agitação constante e, após 30 minutos, lavados três vezes em água esterilizada; em seguida, os explantes foram imersos durante 20 minutos em soluções de diferentes concentrações do fungicida Baytan ${ }^{\circledR}$ e, posteriormente, imersos por 30 minutos em soluções de diferentes concentrações do antibiótico Citrofloxacino, ambos sob agitação constante; por fim, os explantes foram cultivados em meio MS (MURASHIGE; SKOOG, 1962), suplementado com 0,15\% (p/v) de glicose e $0,57 \%(\mathrm{p} / \mathrm{v})$ de ágar e pH ajustado para 5,8 .

A fase de estabelecimento foi realizada em câmara de crescimento a $25 \pm 2^{\circ} \mathrm{C}$ sob fotoperíodo de $16 \mathrm{~h}$ de luz e intensidade luminosa de $50 \mu \mathrm{mol} \mathrm{m} \mathrm{m}^{-2} \mathrm{~s}^{-1}$; após 7, 15 e 21 dias de cultivo, os explantes foram avaliados, considerando-se a contaminação bacteriana e fúngica.

O delineamento utilizado foi inteiramente casualizado (DIC) com arranjo fatorial $3 \times 3$, sendo três concentrações de fungicida $(0,3 ; 0,4$ e $0,5 \%)$ e três concentrações de antibiótico (0; 0,5 e 1,0\%), totalizando 9 tratamentos com 10 repetições cada ( $\mathrm{T} 1=0 \%$ Citrofloxacino + 0,3 Baytan $^{\circledR} ; \mathrm{T} 2=0,5 \%$ Citrofloxacino $+0,3$ Baytan $^{\circledR} ;$ T3 $=1 \%$ Citrofloxacino $+0,3$ Baytan $^{\circledR}$; T4 $=0 \%$ Citrofloxacino $+0,4$ Baytan $^{\circledR} ; \mathrm{T} 5=0,5 \%$ Citrofloxacino $+0,4$ Baytan $^{\circledR} ;$ T6 $=1 \%$ Citrofloxacino $+0,4$ Baytan $^{\circledR} ;$ T7 $=0 \%$ Citrofloxacino $+0,5$ Baytan $^{\circledR} ;$ T8 $=0,5 \%$ Citrofloxacino $+0,5$ Baytan $^{\circledR} ;$ T9 $=1 \%$ Citrofloxacino + 0,5 Baytan ${ }^{\circledR}$.

Cada repetição foi constituída de um frasco de cultivo com um explante por frasco. Os dados obtidos foram transformados em $\sqrt{X+1}$, sendo $\mathrm{X}$ o valor obtido nas avaliações e submetido à análise de variância e analisados pelo teste de médias de Scott-Knott a $10 \%$ de probabilidade. Os dados foram analisados utilizando-se o programa estatístico SAEG 9.1. 


\section{RESULTADOS E DISCUSSÃO}

Quando considerada a contaminação bacteriana, observou-se diferença significativa entre os tratamentos aplicados (Tabela 1), tal como, quando examinada a contaminação por fungos (Tabela 2); no entanto, observou-se, quando avaliada a relação contaminação-tempo, que esse tempo não atuou de forma determinante para o desenvolvimento de colônias bacterianas nos explantes; em contrapartida, foi significante para o aparecimento de maiores taxas de contaminação por fungos (Tabelas 1 e 2).

No tratamento em que se utilizou $1 \%$ de Citrofloxacino $+0,5 \%$ Baytan $^{\circledR}$ (T9), observouse a menor média de contaminação bacteriana (Tabela 1) e fúngica (Tabela 2) ao final dos 21 dias de cultivo; já, quando se utilizou apenas 0,5 (T7) e 0,4\% (T4) do fungicida Baytan ${ }^{\circledR}$, foram verificadas as maiores taxas de contaminação por bactérias, conforme Tabela 3; em contrapartida, as maiores taxas de contaminação fúngica foram observadas quando utilizado o tratamento T8 $\left(0,5 \%\right.$ Citrofloxacino $+0,5 \%$ Baytan $\left.^{\circledR}\right)$, cerca de $90 \%$ (Figura 1).

Tabela 1 - Efeito de diferentes concentrações do antibiótico Citrofloxacino com o fungicida Baytan ${ }^{\circledR}$ na descontaminação de rebentos de sisal, referente ao número médio de rebentos contaminados por bactéria em diferentes períodos de avaliação

\begin{tabular}{cccccc}
\hline & \multicolumn{2}{c}{$\begin{array}{c}\text { Descontaminantes } \\
\text { Citrofloxacino } \\
(\%)\end{array}$} & $\begin{array}{c}\text { Baytan } \\
\text { (\%) }\end{array}$ & $\mathbf{7}$ & \multicolumn{3}{c}{ Contaminação bacteriana } \\
(dias) & $\mathbf{1 5}$ & $\mathbf{2 1}$ \\
\hline T1 & 0 & 0,3 & $1,04 \mathrm{C}$ & $1,04 \mathrm{~b}$ & $1,04 \mathrm{c}$ \\
T2 & 0,5 & 0,3 & $1,00 \mathrm{c}$ & $1,04 \mathrm{~b}$ & $1,12 \mathrm{c}$ \\
T3 & 1 & 0,3 & $1,00 \mathrm{c}$ & $1,04 \mathrm{~b}$ & $1,08 \mathrm{c}$ \\
T4 & 0 & 0,4 & $1,11 \mathrm{~b}$ & $1,21 \mathrm{~b}$ & $1,21 \mathrm{~b}$ \\
T5 & 0,5 & 0,4 & $1,08 \mathrm{C}$ & $1,08 \mathrm{~b}$ & $1,08 \mathrm{c}$ \\
T6 & 1 & 0,4 & $1,20 \mathrm{~b}$ & $1,21 \mathrm{~b}$ & $1,21 \mathrm{~b}$ \\
T7 & 0 & 0,5 & $1,41 \mathrm{a}$ & $1,41 \mathrm{a}$ & $1,41 \mathrm{a}$ \\
T8 & 0,5 & 0,5 & $1,04 \mathrm{C}$ & $1,04 \mathrm{~b}$ & $1,04 \mathrm{c}$ \\
T9 & 1 & 0,5 & $1,04 \mathrm{C}$ & $1,04 \mathrm{~b}$ & $1,04 \mathrm{c}$ \\
\hline
\end{tabular}

Médias com letras diferentes na mesma coluna diferem estatisticamente entre si em nível de $10 \%$ de probabilidade pelo teste de Scott-Knott.

Tabela 2 - Efeito de diferentes concentrações do antibiótico Citrofloxacino com o fungicida Baytan ${ }^{\circledR}$ na descontaminação de rebentos de sisal, referentes ao número médio de rebentos contaminados por fungos em diferentes períodos de avaliação Descontaminantes Contaminação fúngica (dias)

\begin{tabular}{cccccc} 
& $\begin{array}{c}\text { Citrofloxacino } \\
(\%)\end{array}$ & $\begin{array}{c}\text { Baytan }^{\circledR} \\
(\%)\end{array}$ & $\mathbf{7}$ & $\mathbf{1 5}$ & $\mathbf{2 1}$ \\
\hline T1 & 0 & 0,3 & $1,00 \mathrm{~b}$ & $1,21 \mathrm{a}$ & $1,25 \mathrm{~b}$ \\
T2 & 0,5 & 0,3 & $1,00 \mathrm{~b}$ & $1,16 \mathrm{a}$ & $1,21 \mathrm{~b}$ \\
T3 & 1 & 0,3 & $1,33 \mathrm{a}$ & $1,33 \mathrm{a}$ & $1,33 \mathrm{a}$ \\
T4 & 0 & 0,4 & $1,04 \mathrm{~b}$ & $1,08 \mathrm{~b}$ & $1,08 \mathrm{c}$ \\
T5 & 0,5 & 0,4 & $1,08 \mathrm{~b}$ & $1,12 \mathrm{a}$ & $1,16 \mathrm{~b}$ \\
T6 & 1 & 0,4 & $1,21 \mathrm{a}$ & $1,21 \mathrm{a}$ & $1,21 \mathrm{~b}$ \\
T7 & 0 & 0,5 & $1,00 \mathrm{~b}$ & $1,00 \mathrm{~b}$ & $1,00 \mathrm{c}$ \\
T8 & 0,5 & 0,5 & $1,33 \mathrm{a}$ & $1,37 \mathrm{a}$ & $1,37 \mathrm{a}$ \\
T9 & 1 & 0,5 & $1,00 \mathrm{~b}$ & $1,04 \mathrm{~b}$ & $1,04 \mathrm{c}$ \\
\hline
\end{tabular}

Médias com letras diferentes na mesma coluna diferem estatisticamente entre si em nível de $10 \%$ de probabilidade pelo teste de Scott-Knott. 


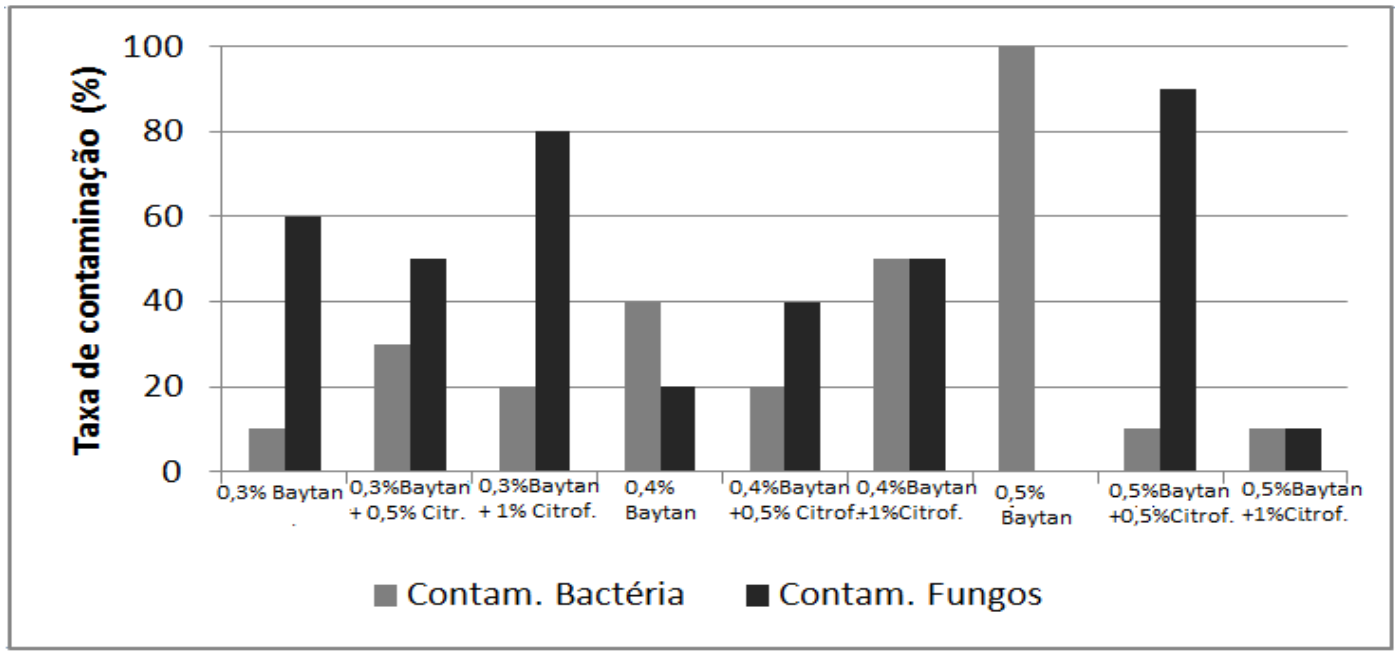

Figura 1 - Taxa de contaminação dos explantes de sisal, utilizando-se diferentes concentrações de fungicida e antibiótico.

As altas taxas de contaminação bacteriana nos tratamentos em que se utilizou apenas o fungicida com 0,5 (T7) e 0,4\% (T4) do fungicida Baytan ${ }^{\circledR}$ (Figura 1) estão associadas ao fato de, nesses tratamentos, não ter sido aplicada solução antibiótica, o que elevou a probabilidade de contaminação dos explantes por bactérias diversas. De acordo com Pereira, Mattos e Fortes (2003), os maiores problemas, em relação à contaminação no cultivo in vitro, referemse à contaminação bacteriana, uma vez que estas apresentam um período maior de latência e desenvolvimento assintomático, tornando-se visíveis após algum tempo de cultivo.

Já, a alta taxa de contaminação fúngica observada quando utilizado $0,5 \%$ de antibiótico $+0,5 \%$ de fungicida (T8), reforça o fato dos contaminantes do explante serem de origem endógena e de possuírem alta resistência, visto que, nesse tratamento, foi administrada a maior concentração do fungicida e esta ainda se mostrou ineficiente.

O fato da fonte doadora de explantes ter sido obtida diretamente do campo, pode ter aumentado as chances de contaminação. De acordo com Erig e Fortes (2002), maiores taxas de contaminação são observadas quando utilizadas plantas doadoras de explantes diretamente do campo.

Em contrapartida, quando utilizado $1 \%$ Citrofloxacino $+0,5 \%$ de $\operatorname{Baytan}^{\circledR}$ (T9), a concentração máxima do antibiótico e do fungicida ampliou o espectro de atuação e, consequentemente, o desenvolvimento de explantes saudáveis ao longo do período de estudo, reduzindo, então, a taxa de contaminação bacteriana e fúngica a $10 \%$ do total de explantes cultivados (Figura 1).

Os resultados obtidos neste trabalho reforçam a afirmativa proposta por Montarroyos (2000) e por Erig e Schuch (2003) da necessidade de um controle das condições fitossanitárias da planta utilizada como fonte doadora de explantes. 


\section{CONCLUSÕES}

A utilização do fungicida Baytan ${ }^{\circledR}$ e do antibiótico Citrofloxacino isolados e combinados é fundamental na descontaminação de rebentos de sisal obtidos de plantas originárias do campo, sendo a combinação mais promissora $0,5 \%$ de Baytan $^{\circledR}$ associada a $1 \%$ de Citrofloxacino. A morfogênese dos explantes não é afetada quando utilizadas as concentrações máximas dos agentes contaminantes.

\section{REFERÊNCIAS}

ALVES, M. O.; SANTIAGO, E. S.; LIMA, A. R. M. Diagnóstico socioeconômico da região nordestina produtora de sisal (versão preliminar). Fortaleza: Banco do Nordeste do Brasil, 2004.

CARVALHO, J. M. F.; SENA, D. V. A. Técnicas de Cultivo In Vitro no sisal. Campina Grande: Embrapa - Algodão, 2008.

ERIG, A. C.; FORTES, G. R. L. Estabelecimento de pereira (Pyrus spp.) in vitro a partir de meristemas e gemas. Cienc. Rural, Santa Maria, v. 32, n. 4, p. 577-582, 2002.

ERIG, A. C; SCHUCH, M. W. Tipo de explante e controle da contaminação e oxidação no estabelecimento in vitro de plantas de macieira (Malus domestica Borkh.) Cvs. Galaxi, Maxigala e Mastergala. Rev. bras. agrocienc, Pelotas, v. 9, n. 3, p. 221-227, 2003.

INSTITUTO BRASILEIRO DE GEOGRAFIA E ESTATÍSTICA (IBGE). Levantamento sistemático da produção agrícola. Rio de Janeiro: Ministério do Planejamento, Orçamento e Gestão.126p., 2013.

LIMA, E. F. et al. Podridão vermelha do tronco do sisal (agave sisalana perr.) causada por botryodiplodia theobromae pat. Rev. Bras. OI. Fibros., Campina Grande, v. 2, n. 2, p. 109112, 1998.

MONTARROYOS, A. V. V. Contaminação in vitro. ABCTP Notícias, Brasília, n. 36, p. 5-10, 2000.

MORAES, A. M.; ALMEIDA, F. A. C.; CAZÉ FILHO, J. Desinfestação e estabelecimento in vitro de gemas axilares de abacaxizeiro. Rev. Tecnol. Ciên. Agropec., João Pessoa, v. 1, n. 2, p. 39-44, 2007.

MURASHIGE, T.; SKOOG, F. A revised medium for rapid growth and bioassays with tobacco culture. Physiol. plant., Copenhagen, v. 15, p. 473-497, 1962.

ODA, M. L. et al. Avaliação da fitotoxicidade de fungicidas e germicida na propagação in vitro de Oncidium varicosum Lindl. (Orchidaceae) para o controle de microorganismos. Semin.: Cienc. agrar., Londrina, v. 24, n. 2, p. 273-276, 2003.

PEREIRA, G. A. et al. Controle de contaminação em explantes de bananeira 'Grande Naine' 
na micropropagação in vitro. Rev. Tecnol. Ciên. Agropec., João Pessoa, v. 4, n. 2, p. 35-39, 2010.

PEREIRA, J. E. S.; FORTES, G. R. L. Toxicidade de antibióticos no cultivo in vitro da batata em meios semi-sólido e líquido. Pesq. agropec. bras., Brasília, v. 38, n. 11, p. 1273-1279, 2003.

PEREIRA, J. E. S.; MATTOS, M. L. T.; FORTES, G. R. L. Identificação e controle com antibióticos de bactérias endofíticas contaminantes em explantes de batata micropropagados.

Rev. bras. agrocienc., Pelotas, v. 38, n. 7, p. 827-834, 2003.

ROSALES, M. S. D. et al. El cultivo in vitro como herramienta para el aprovechamento, mejoramiento y conser vación de espécies del gênero Agave. Invest. cienc., Barcelona, v. 41, p. 53-62, 2008.

SILVA, O. R. R. F.; BELTRÃO, N. E. M. O Agronegócio do sisal no Brasil. Campina Grande: Embrapa - Algodão, 1999.

SILVA, R. M. S.; BLANK, M. F. A.; ÂNGELO, P. C. S. Desinfestação de explantes de inhame roxo (Dioscorea rotundata. Poir) coletados no campo para micropropagação. In: CONGRESSO BRASILEIRO DE FLORICULTURA E PLANTAS ORNAMENTAIS, 14., CONGRESSO BRASILEIRO DE CULTURA DE TECIDOS, 1., 2003, Lavras. Resumos... Lavras: UFLA/FAEPE, 2003. p. 329.

STANIER, I.; KHOSH-KHUI, M. A simple procedure for disinfection of "baby masquerade" miniature rose explants. Scientia Horticuturae, Amsterdam, v. 68, p. 145-148, 1997. 